\title{
FISCAL POLICY AND THE PERFORMANCE OF PRIVATE SECTOR IN NIGERIA (1990-2019): A VECTOR ERROR CORRECTION INVESTIGATION
}

\section{Andabai Priye Werigbelegha (Ph.D)}

Department of Banking and Finance. Niger Delta University, Bayelsa State, Nigeria.

\section{Cite this article:}

Andabai Priye Werigbelegha (2021), Fiscal Policy and the Performance of Private Sector in Nigeria (1990-2019): A Vector Error Correction Investigation. African Journal of Accounting and Financial Research 4(2), 94-103. DOI: 10.52589/AJAFR-TF39IX73.

\section{Manuscript History}

Received: 17 Nov 2020

Accepted: 12 Dec 2020

Published: 20 July 2021

Copyright $\left({ }_{0} 2020\right.$ The Author(s). This is an Open Access article distributed under the terms of Creative Commons AttributionNonCommercial-NoDerivatives 4.0 International (CC BY-NC-ND 4.0 ), which permits anyone to share, use, reproduce and redistribute in any medium, provided the original author and source are credited.
ABSTRACT: The study examines the relationship between fiscal policy and the performance of private sector in Nigeria; for the period 1990-2019. Secondary data are collected from Central Bank of Nigeria Statistical Bulletin, 2019. Four variables are employ for this study. These are Private Sector Output as proxy for performance of private sector economy and used as the dependent variable; whereas, the explanatory variables include Tax, Recurrent Expenditure and Capital Expenditure. Hypotheses are formulated and tested using time series econometric models. The result confirms that about $68 \%$ shortrun adjustment speed from long-run disequilibrium. The study shows a significant relationship between capital expenditure and private sector output in Nigeria. Taxation has a significant relationship with private sector output in Nigeria. Recurrent expenditure has a significant relationship with private sector output in Nigeria. The coefficient of determination indicates that about $62 \%$ of the variations in economic growth can be explain by changes in fiscal policy variables in Nigeria. The study concludes that fiscal policy has a significant relationship with the growth and development of Nigerian economy. The study recommends that more resources should be relocated to productive sectors and increasing and sustaining a spending on the productive sectors of the economy. The study suggested that Nigerian government should put a stop to the incessant unproductive foreign borrowing, wasteful spending and uncontrolled money supply. The government should embark on specific policies aimed at achieving increased and sustainable growth and development in the economy.

KEYWORDS: Fiscal Policy, Performance, Private Sector, Economy, Nigeria 


\section{INTRODUCTION}

In any modern economy a vibrant government fiscal policy serves as a catalyst for private sector growth and development. Thus, government capital expenditure through fiscal policy appears to have continuous increase overtime in Nigeria (Olayiwola \& Busari, 2017). However, government spending on capital intensive projects will improve the welfare of the people and facilitate production of goods and services across all sectors of the economy which could leads to stimulate private sector growth. Hence, the work of Adewuyi and Adeoye (2017) stated that capital expenditure has increased rapidly during the last two decades and without a corresponding increase in growth and development of the private sector economy. Study carried out by Umeora and Andabai (2015) posited that the economists have generally concentrated their attention on the theory of taxation. However, the theory of government capital expenditure has been more or less confined to those generalities in terms of its impact on the private sector growth.

Hence, the input of recurrent expenditure on private sector growth has continued to generate series of debate among scholars in Nigeria. Consequently, Government performs two basic functions of protection and provision of public necessities such as defense, roads, education, health and power etc. Because, an increase in capital expenditure on socio-economic and physical infrastructures encourage private sector growth and development. Similarly, such expenditure on infrastructure like: roads, communication, power etc. reduced production cost, increase private sector investments. Study carried out by Chiugbu and Adenekinju (2018) stated that in order to maintain a steady rate of growth and development of private sector economy; fiscal policy is expected to play a major role. The work of Podrecca and Carmeci (2018) posited that in order to increase real sector growth in the developing economies, government capital expenditure plays a crucial role; because, it facilitates social overhead, roads, electricity, that has assisted in market expansion and rate of investment.

In Nigeria, government spending over the years has sky-rocketed; but, the private sector economy is still struggling under the shackles of under-development when compared with her counterparts in Asia (Malaysia, Pakistan, Indonesia, Iran, India, Thailand and Bangladesh), which Nigeria was ranked ahead of in the 1960's in terms of growth potentials (Rukyatu \& Kumalu, 2018). Thus, the study by Azeez and Aliyu (2018) revealed that government capital expenditure has continued to rise over years due to huge receipts from production, increased demand for public goods like communication, roads, health and power. Hence, the persistent rise in government capital expenditure has not translated to meaningful growth and development in the private sector economy of Nigeria (Andabai, 2014). These conflicting problems created a knowledge gap in this study; therefore, it is against this background that the study attempts to investigate the effect of government fiscal policy on the performance of private sector economy in Nigeria.

\section{Theoretical Framework}

The theoretical frame work of this study is predicated on Wagner's theory of increasing state activities of (1917). The theory stated that the extension of state functions leads to an increase in public expenditure on administration and regulation in the economy. The development of modern industrial society would give rise to increasing political pressure for social progress and call for social consideration in the conduct of the economy. The raise in public expenditure will leads to increase in private sector performance in Nigeria. The structure characteristics of 
government domestic debt discussed-including, composition, investor base and maturity structure have important implications for the conduct of monetary policy and for the development of the financial sector in general (Sikiru \& James, 2017). The composition of the market has been mainly in favor of short-term treasury bills. Currently, the CBN could finance any deficit and refinance maturing debt easily with the frequent sales of large quantities of short-term treasury bills. But this simply concentrates government indebtedness to the most liquid sector of the market; short maturing treasury bills. Issuing securities at large maturities reduces to some extent the liquidity of the securities market. Large maturing debt is inherently less liquid than short-term debt. The Central Bank of Nigerian has tried to control excess liquidity in the banking system either using stabilization securities to mop up the excess, or by changing liquidity ratio requirements. However, this policy is always frustrated by the regular issuance of more short term treasury bills which immediately restores high liquidity in the system thereby impeding monetary policy conduct. Generally regular liquidity mops up exercises by the Central Bank are hampered by the frequent sales of short term treasury bills (Chiugbu \& Adenekinju, 2017).

\section{Empirical Review}

Agboenda (2018) investigated the nexus between fiscal policy and real sector growth in Nigeria (1996-2017). Using multiple regression analysis, adopting private sector output as proxy for real sector growth and tax revenue, government recurrent expenditure budget and government capital expenditure budget as the explanatory variables argued that significant relationship exist between fiscal policy variable jointly and economic growth and that the specific variable contributing to the GDP are government recurrent and capital expenditures.

Madugbe and Ndalla (2017) evaluated the effect of government fiscal policy on Nigeria's economic growth (1998-2017). The study used Gross Domestic Product as the dependent variable and federal government expenditure, federal government revenue, inflation rate and capital inflow as the regressor and by adopting arcane method of OLS techniques argued that they exist long run equilibrium relationship between fiscal policy variable and economic growth in Nigeria. Omitogun and Ayinla (2017) examined fiscal policy and Nigerian economy (1990-2016) using Ordinary Least Square method claimed that fiscal policy has been effective in the area of promoting sustainable economic growth. They used gross domestic product as proxy for economic growth representing and money printing financed deficits were used as explanatory variables.

Balaji and Yusuf (2020) investigated fiscal policy and economic growth relationship in Nigeria (1997-2019) using the Engle-Granger approach to co-integration test, stated that productive expenditure was found to be statistically significant. They utilized logarithms of real gross domestic product as proxy for economic growth representing the dependent variable while the independent variables were the logarithms of productive government consumption expenditure (defined as total recurrent expenditure less recurrent expenditure on health, education and economic services), direct income tax, and capital expenditure.

Ojikoi and Yuhua (2020) examined the contribution of fiscal policy in the achievement of sustainable economic growth in Nigeria using Slow growth model estimated with the use of ordinary least square method. It was found that fiscal policy has not been effective in the area of promoting sustainable economic growth in Nigeria. They however, stated that factors such 
as wasteful spending, poor policy evident in Nigeria which are indeed capable of hampering the effectiveness, of fiscal policy has made it impossible to come up with such a conclusion.

Mojuo (2019) examined at the nexus of unemployment and growth in Nigeria (1995-2019). On major findings of the study is that the economy grew by $55.5 \%$ between $1999-2015$ and the population increased by $36.4 \%$. This should ordinarily have resulted to a decrease in the rate of unemployment but rather unemployment increased by $74.8 \%$. Osuwqi and Shahu (2020) studied fiscal policy formulation and implementation in oil producing countries. Their study showed that resource dependent economies tend to grow more slowly than non-resource dependent ones at comparable level of development. Poverty is skill wide spread in a number of oil-producing countries. They concluded that a pattern of fluctuating fiscal expenditures associated with oil volatility has entailed significant economic and social costs for a number of oil producers. Ogbole, Amadi and Essi (2011) wrote on fiscal policy; its impact on economic growth in Nigeria (1970-2006). The study involves comparative analysis of the impact of fiscal policy on economic growth in Nigeria during regulation and deregulation periods. Econometrics analysis of time series data from central Bank of Nigeria was conducted. Results showed that there is difference in the effectiveness of fiscal policy targets and diversification of the nation's economic base, among other, was recommended.

Chiubgu (2019) examined the effect of monetary and fiscal policy interactions in Nigeria between 1990-2018. The study examined the nature of fiscal policies in Nigeria using vector anto-regression (VAR) model. The evidence indicates that monetary and fiscal policies in Nigeria have interacted in a counteractive manner for most of the sample period (1990-2018). while at other periods no symmetric pattern of interaction between the two policy variables was observed. Ozuoju and Ayigbe (2018) examined fiscal policy and economic growth in Nigeria. They used Solow growth model estimated with the use of ordinary least square method and found out that fiscal policy has not been effective in the area of promoting sustainable economic growth in Nigeria. They suggested that Nigerian government should put a stop to the incessant unproductive foreign borrowing, wasteful spending and uncontrolled money supply and embark on specific policies aimed at achieving increased and sustainable productivity in all sectors of the economy.

\section{METHODOLOGY}

The ex-post-facto research design was used; because, the data are already documented by reputable institutions like the World Bank, International Monetary Fund (IMF), Central Bank of Nigeria (CBN) and National Bureau of Statistics. Thus, researchers adapt and rely on such official publications for valid and reliable academic exercise (Ibenta, 2012). The study used Private Sector Output as proxy for the performance of private sector economy and used as the dependent variable; whereas, the explanatory variables include Tax, Recurrent Expenditure and Capital Expenditure as stated in appendix $\mathbf{1}$.

\section{Model Specification}

Multivariate linear regression models are used to test each of the null hypotheses proposed for this study. Based on the three formulated hypotheses, the study adapted a model from the work of (Umeora \& Andabai, 2015). This model is stated as follows: GDP $=f(\mathrm{CE}, \mathrm{RE}, \mathrm{TAX})$ 
African Journal of Accounting and Financial Research

ISSN: 2682-6690

Volume 4, Issue 2, 2021 (pp. 94-103)

www.abjournals.org

Where: GDP $=$ Gross Domestic Product as proxy for Economic Growth, $\mathrm{CE}=$ Capital Expenditure, $\mathrm{RE}=$ Recurrent Expenditure, $\mathrm{TAX}=$ Government Taxation

The above model is modified in this study by introducing Private Sector Output and was employed as dependent variable. Hence, the modified model was stated as:

$\mathrm{PSO}=f(\mathrm{CE}, \mathrm{RE}, \mathrm{TAX})$

The econometric form can be written as:

$\operatorname{LnPSO}=\mathrm{a}_{0}+\mathrm{a}_{1} \operatorname{LnCE}+\mathrm{a}_{2} \operatorname{LnRE}+\operatorname{Ln} \mathrm{a}_{3} \mathrm{TAX}+\mu \ldots \ldots \ldots . .(2)$.

Where: PSO = Private Sector Output as proxy for performance of private sector economy

$\mathrm{CE}=$ Capital Expenditure, $\mathrm{RE}=$ Recurrent Expenditure, $\mathrm{TAX}=$ Taxation

$\mathrm{a}_{0}=$ Constant parameter, $\mathrm{a}_{1}-\mathrm{a}_{3}=$ Elasticity Co-efficient of each variable. $\mu=$ Stochastic error term, $\mathrm{Ln}=$ The natural $\log$ of the variables. Log transformation is necessary to reduce the problem of heteroskedasticity because it compresses the scale in which the variables are measured, thereby reducing a tenfold difference between two values to a twofold difference (Gujarati, 2004).

\section{DATA PRESENTATION AND DISCUSSION}

The study centered on the relationship between fiscal policy and the performance of private sector economy in Nigeria; for the period 1990-2019. The study used private sector output as proxy for the performance of private sector economy and used as the dependent variable; whereas, the explanatory variables include tax, recurrent expenditure and capital expenditure as indicated in appendix $\mathbf{1}$.

Table 1: Descriptive statistics

$\begin{array}{lcccc} & \text { PSO } & \text { CE } & \text { RE } & \text { TAX } \\ \text { Mean } & 84937.88 & 86347.28 & 75637.50 & 48.37853 \\ \text { Median } & 30362.70 & 43193.80 & 86765.12 & 44.16480 \\ \text { Maximum } & 68570.35 & 72534.43 & 56137.45 & 62.13620 \\ \text { Minimum } & 55619.30 & 46376.56 & 31527.25 & 35.36200 \\ \text { Std. Dev. } & 51036.02 & 148.6905 & 53826.49 & 9.348232 \\ \text { Skewness } & 72734.20 & 31112.48 & 10116.44 & 0.158376 \\ \text { Kurtosis } & 31003.65 & 14194.50 & 53759.20 & 2.238517 \\ & & & & \\ \text { Jarque-Bera } & 0.350204 & 218.7151 & 12826.39 & 0.336209 \\ \text { Probability } & 0.790269 & 0.000000 & 0.001232 & 0.836799 \\ & & & & \\ \text { Sum } & 162.1930 & 3173.310 & 487.4000 & 1573.929 \\ \text { Sum Sq. Dev. } & 1158.357 & 685374.4 & 907.4760 & 2164.166 \\ & & & & \\ \text { Observations } & 30 & 30 & 30 & 30\end{array}$

Source: E-views 9.1 output 
Descriptive statistics on table 1 shows that private sector output (PSO) for the period under study had a mean value of $\$ 82,937.88$, capital expenditure had $\$ 86,347.28$, and recurrent expenditure had $\$ 75,637.50$ while Taxation had $48.37 \%$. The Jarque-Bera statistic shows that two of the variables, namely private sector output (PSO) and recurrent expenditure were normally distributed while government recurrent expenditure and taxation were highly skewed. Furthermore, capital expenditure has a mean of $\$ 86,347.28$ this implies that for the period under review the capital expenditure was very high. This is because, capital expenditure contributed significantly to the growth and development of private sector-led economy in Nigeria.

\section{Unit Root Test}

The stationary test of the variables was done using the Augmented Dicker Fuller (ADF) Unit Root Test. The result on table 2 shows that all the variables are integrated at first difference i.e. $1(1)$ at the $5 \%$ or $1 \%$ level of significance.

Table 2: Unit Root Tests Analysis

\begin{tabular}{|l|l|l|l|l|}
\hline \multicolumn{1}{|c|}{ Variables } & \multicolumn{1}{c|}{$\begin{array}{c}\text { ADF test } \\
\text { Statistics }\end{array}$} & $\begin{array}{c}\text { Mackinnon } \\
\text { critical @ 5\% }\end{array}$ & $\begin{array}{c}\text { No of the time } \\
\text { difference }\end{array}$ & Remark \\
\hline PSO & 6.3627452 & -4.859043 & I(1) & Stationary \\
CE & -3.1537684 & -5.957697 & I(1) & Stationary \\
RE & -4.8576904 & -4.756584 & I(1) & Stationary \\
TAX & 5.2324253 & 2.869763 & I(1) & Stationary \\
\hline
\end{tabular}

Notes: (1)1\% level of significance, $5 \%$ level of significance, $10 \%$ level of significance. The tests accepted at $5 \%$ level of significance. Source: Researcher's Estimation using- E-views 9.1.

\section{Test for Co-Integration}

Thus, having found that all the variables are stationary at first difference, the next step is to perform Johansen co-integration procedure to ascertain whether private sector output (PSO), capital expenditure (CE), recurrent expenditure (RE) and tax (TAX) are co-integrated in the same order. The results of the test are presented on table 3.

Table 3: Multivariate Johansen's Co-Integration Test Result.

\begin{tabular}{|l|l|l|l|l|l|l|}
\hline $\begin{array}{l}\text { Null } \\
\text { hypotheses }\end{array}$ & $\begin{array}{l}\text { Alternative } \\
\text { hypotheses }\end{array}$ & $\begin{array}{l}\text { Eigen } \\
\text { value }\end{array}$ & $\begin{array}{l}\text { Likelihood } \\
\text { ratio }\end{array}$ & $\begin{array}{l}\text { Critical } \\
\text { vales 5\% }\end{array}$ & $\begin{array}{l}\text { Critical } \\
\text { value 1\% }\end{array}$ & $\begin{array}{l}\text { Hypothesized } \\
\text { No. of CE(s) }\end{array}$ \\
\hline $\mathrm{r}=0$ & 0.668677 & 56.364876 & 58.36 & 44.08 & None ** \\
\hline $\mathrm{rd} \leq 1$ & $\mathrm{r}=2$ & 0.638676 & 43.759783 & 44.29 & 38.53 & At most 1 \\
\hline $\mathrm{rd} \leq 2$ & $\mathrm{r}=3$ & 0.585669 & 36.285387 & 36.42 & 29.13 & At most 2 \\
\hline $\mathrm{rd} \leq 3$ & $\mathrm{r}=4$ & 0.486970 & 24.537603 & 24.25 & 27.87 & At most 3 \\
\hline
\end{tabular}

Source: E-views Econometrics 9.1. Note* (**) denotes rejection of hypothesis at $5 \%(1 \%)$ significance level. 
African Journal of Accounting and Financial Research

ISSN: 2682-6690

Volume 4, Issue 2, 2021 (pp. 94-103)

www.abjournals.org

\section{Vector Error Correction Model}

The Error Correction coefficient contains information about whether the past values affect the current values of the variable under study and the significant coefficient implies that past equilibrium errors play a role in determining the current outcomes (Ibenta, 2012).

\section{Table 4: Vector Error Correction Estimates Results}

Dependent Variable: PSO

Method: Least Squares, Time: 06:30

Sample: 1990-2019

Included observations: 30

\begin{tabular}{lllll} 
Date: $06 / 02 / 2020$ & Coefficient & Std. Error & t-Statistic & Prob. \\
\hline \hline (ECM)(-1) & -0.683463 & 0.076984 & 16.24383 & 0.00035 \\
D(PSO-1) & 3.748580 & 0.056743 & 5.867665 & 0.00025 \\
D(PSO-2) & 7.568529 & 0.007887 & 4.375649 & 0.00038 \\
C & 4.630554 & 0.008693 & 1.364648 & 0.00023 \\
Ln(CE) & 8.465879 & 0.658709 & 0.127385 & 0.00254 \\
Ln(RE) & 6.567485 & 0.029787 & 2.437892 & 0.00032 \\
Ln(TAX) & 5.275978 & 0.058859 & 3.132479 & 0.00324 \\
\hline \hline R-squared & 0.620464 & Mean dependent var & 132.3220 \\
Adjusted R-squared & 0.580143 & S.D. dependent var & 35.83676 \\
S.E. of regression & 12.85095 & Akaike info criterion & 123.2359 \\
Sum squared resid & 32263.10 & Schwarz criterion & 10.46039 \\
Log likelihood & -18.1673 & F-statistic & 6.967846 \\
Durbin-Watson stat & 1.976854 & Prob(F-statistic) & 0.000000 \\
\hline \hline
\end{tabular}

Source: Author's computation with the use of E-view 9.1

The results on table 4 show that error-correction coefficient $(-0.683463)$ is statistically significant and has a negative sign, which confirms a necessary condition for the variables to be co-integrated. Hence, a long-run equilibrium relationship exist between fiscal policy and the private sector economy in Nigeria; and, the result confirms that about 68\% short-run adjustment speed from long-run disequilibrium. The coefficient of determination $\left(\mathrm{R}^{2}=0.620464\right)$ indicates that about $62 \%$ of the variations in performance of private sector economy can be explained by changes in fiscal policy variables (RE, CE, TAX) in Nigeria. This implies that a significant portion of the performance of private sector economy is explained by fiscal policy variables. The F-Statistics of (6.967846) which is significant at 5\% confirms the relationship between fiscal policy and the performance of private sector economy in Nigeria; for the period 1990-2018. The influence of the explanatory variables on the dependent variable is statistically significant and this is also confirmed by the F-probability which is statistically zero.

\section{Test of Hypotheses}

Ho1: Capital expenditure has no significant relationship with the private sector output in Nigeria. Decision Criteria, Level of significance $(\alpha)$ : $0.05(5 \%)$. Decision Rule: Reject $\mathrm{H}_{0}$ : If 
p- value $<0.05$ and accept $\mathrm{H}_{0}$ if $\mathrm{p}$ - value $>0.05$. The results on table 4 show that capital expenditure has a t-statistic of 0.127385 with a probability of 0.000254 which is lower than the level of significance of 0.05 , which means, its relationship is statistically significant. The null hypothesis is, thus, rejected. Thus, capital expenditure has a significant relationship between with the private sector output in Nigeria. Ho2: Revenue expenditure has no significant relationship with the private sector output in Nigeria. Decision Rule: Reject $\mathrm{H}_{0}$ : If p- value < 0.05 and accept $\mathrm{H}_{0}$ if $\mathrm{p}$ - value $>0.05$. The results on table 4 show that capital expenditure has a t-statistic of 2.437892 with a probability of 0.000032 which is lower than the level of significance of 0.05 , which means, hence, its relationship is statistically significant. The null hypothesis is, therefore, rejected. Thus, revenue expenditure has a significant relationship with private sector output in Nigeria. Ho3: Tax has no significant effect on private sector output in Nigeria. Decision Rule, Reject $\mathrm{H}_{0}$ : If $\mathrm{p}$ - value $<0.05$ and accept $\mathrm{H}_{0}$ if $\mathrm{p}$ - value $>0.05$, The results on table 4 show that tax has a t-statistic of 3.674769 with a probability of 0.000324 which is lower than the level of significance of 0.05 , which means, hence, its relationship is statistically significant. The null hypothesis is therefore rejected. Hence, tax has a significant relationship with private sector output in Nigeria.

\section{CONCLUSION AND RECOMMENDATIONS}

The study concludes that fiscal policy has a significant relationship between with the growth and development of private sector economy in Nigeria. This is consistent with the work of Andabai (2014) which revealed that private sector development has a significant relationship with economic growth in Nigeria. Hence, the intervention of the Government in an economy through fiscal policy has been to manipulate the receipt and expenditure of its budget in other to achieve macro-economic objectives (Ogbejuana, 2017). Thus, the study recommends that more resources should be relocated to productive sectors and increasing and sustaining a spending on the productive sectors of the economy. The study suggested that Nigerian government should put a stop to the incessant unproductive foreign borrowing, wasteful spending and uncontrolled money supply. The government should embark on specific policies aimed at achieving increased and sustainable growth and development in the economy. Monetary authority and policy makers should encourage banks to set up more branches in the rural areas in order to encourage rural based investors through private sector investments in the economy.

\section{REFERENCES}

Adeleye, J. O \& Adewuyi, M. O (2016). Impact of international trade on economic growth in Nigeria. International Journal of Financial Research. 1(6), 3-12.

Adelowokan, O. A \& Maku, A.O (2017). Trade openness, foreign investment and economic growth in Nigeria: A long-run analysis. European Journal of Globalization and Development Research, 7(1), 446-458

Adenugba, A. A \& Dipo, S. O (2016). Non-oil exports in the economic growth of Nigeria: A Study of agricultural and mineral resources. Journal of Educational and Social Research, 23(2), 12-19. 
Adewuyi, A \& Adeoye, D (2017). Attainment of potential growth rates in Nigeria under balance of payments constraints: The way forward. Research Journal of Finance and Accounting. 2(3), 22-29.

Andabai, Priye W. (2014). Private sector development and economic growth in Nigeria. International Journal of Advanced Research in Statistics, Management and Finance, 2(1), 15-25.

Azeez, B. \& Aliyu, F. (2018). Effect of international trade on Nigerian economic growth: An empirical investigation. International Journal of Economics and Management, 6(4), 130142.

Boardman, A (2006). Ownership and performance in competitive environments: A comparison of the performance of private, mixed and state owned enterprises. Journal of Law and Economics, 32 (1), 30-44.

Chiugbu, G. \& Adenekinju, A. (2018). Trade policy and productivity growth. Global Journal of Economics and Management Studies, 8(4), 218-230.

Ibenta, Steve N.O. (2012). Research Monograph: Guidelines for Seminar Papers, Theses Project Reports. 22-28 Regina Caeli Road, Awka, Anambra State.

Ihenetu, Hyginus I. \& Nwiyordee, Austin N. (2016). The limiting factor and the performance of the manufacturing sector in Nigeria: An empirical analysis. Journal of the Faculty of Business Studies, 2 (1\&2), 70-84.

Nnanna, G. K. (2017). Financial small-scale business under the new CBN. Directive and its likely impact on industrial growth. CBN Bullion. 25(5), 36-49.

Nzotta, S. M (2014). Money, Banking and Finance: Theory and Practice. Revised Edition, Hudsion-Jude. Owerri, Nigeria.

Ogbejuana, R. (2017). International trade and the growth and development of Nigeria: Empirical analysis. European Journal of Business Research, 11(28), 23-19.

Ojikoi, S \& Yuhua, M. K (2020). Contribution of fiscal policy in the achievement of sustainable economic growth in Nigeria. Asian Journal of Finance, Economics and Managerial Studies, 12(4), 418-430.

Olaleye, S. O., Edun, F., \& Taiwo, S. B. (2013). Export diversification and economic growth in Nigeria: An empirical test of relationship using a granger casualty test. Journal of Emerging Trends in Economics and Management Sciences, 5(1), 70-79

Olayiwola, K \& Busari, R (2017). Economic reform programme and private sector development in Nigeria. Development Policy Centre Research. Report No 35, Ibadan, Nigeria.

Podrecca, E \& Carmeci, G (2018). Fixed Investment and Economic Development: New results on causality. Journal of Economics and Managerial Research, 3(3), 177-182.

Rukyatu, S \& Kumalu, R (2018). Impact of domestic and external debt on the economic growth of Pakistan. Journal of Applied Economics Studies, 20(1), 120-129.

Sikiru, O. A. \& James, O. A. (2017). Exploration of the impact of international trade on the growth of Nigeria's manufacturing sector: 1975-2010. Journal of Business Administration and Management Sciences Research. 3(1), 006-011.

Ugochinyere, F. (2017). The public debt and economic growth: An empirical investigation. European Journal of Finance and management Research, 23(8), 243-254.

Umeora, C. E \& Andabai, Priye W. (2015). Tackling persistent fiscal deficits through macroeconomic reforms in Nigeria. Journal of Banking \& Financial Studies, 1(1), 6-16. 


\section{APPENDIX}

\section{Effect Fiscal Policy on Private Sector Output in Nigeria (1990-2019)}

\begin{tabular}{|c|c|c|c|c|}
\hline Years & $\begin{array}{c}\text { Private Sector } \\
\text { Output } \\
\text { („'billion) }\end{array}$ & $\begin{array}{c}\text { Capital Expend. } \\
\text { (\#' Billion) }\end{array}$ & $\begin{array}{c}\text { Tax Rate } \\
(\%)\end{array}$ & $\begin{array}{c}\text { Recurrent } \\
\text { Expenditure ( } \\
\text { Billion) }\end{array}$ \\
\hline 1990 & 157.3 & 33.55 & 25.50 & 52.86 \\
\hline 1991 & 218.5 & 41.35 & 20.01 & 75.40 \\
\hline 1992 & 311.8 & 58.12 & 29.80 & 111.11 \\
\hline 1993 & 253.9 & 127.12 & 18.32 & 165.34 \\
\hline 1994 & 453.9 & 143.42 & 21.00 & 230.29 \\
\hline 1995 & 745.6 & 180.00 & 20.18 & 289.09 \\
\hline 1996 & 896.4 & 238.60 & 19.74 & 345.85 \\
\hline 1997 & $1,099.0$ & 316.21 & 13.54 & 413.28 \\
\hline 1998 & $2,417.3$ & 351.96 & 18.29 & 488.15 \\
\hline 1999 & $3,401.7$ & 431.17 & 21.32 & 628.95 \\
\hline 2000 & $3,474.6$ & 530.37 & 17.98 & 878.46 \\
\hline 2001 & $3,154.3$ & 764.96 & 18.29 & $1,269.32$ \\
\hline 2002 & $3,727.0$ & 930.49 & 24.85 & $1,505.96$ \\
\hline 2003 & $5,618.7$ & $1,096.54$ & 20.71 & $1,952.92$ \\
\hline 2004 & $5,353.4$ & $1,421.66$ & 19.18 & $2,131.82$ \\
\hline 2005 & $6,158.1$ & $1,838.39$ & 17.95 & $2,637.91$ \\
\hline 2006 & $7,946.8$ & $2,290.62$ & 17.26 & $3,797.91$ \\
\hline 2007 & $8,688.5$ & $3,668.66$ & 16.94 & $5,127.40$ \\
\hline 2008 & $11,069.5$ & $6,920.50$ & 15.14 & $8,008.20$ \\
\hline 2009 & $13,817.4$ & $9,110.86$ & 18.99 & $9,419.92$ \\
\hline 2010 & $15,321.9$ & $10,157.02$ & 17.59 & $11,034.94$ \\
\hline 2011 & $18,221.3$ & $10,660.07$ & 16.02 & $12,172.49$ \\
\hline 2012 & $17,820.4$ & $14,649.28$ & 16.79 & $13,895.39$ \\
\hline 2013 & $26,116.8$ & $15,778.31$ & 16.72 & $15,158.62$ \\
\hline 2014 & $28,324.0$ & $17,128.98$ & 16.55 & $17,680.52$ \\
\hline 2015 & $29,753.3$ & $17,895.26$ & 18.2 & $19,772.87$ \\
\hline 2016 & $30,278.2$ & $17,357.18$ & 18.9 & $19,988.30$ \\
\hline 2017 & $31,097.9$ & $16,364.64$ & 18,45 & $17,756.84$ \\
\hline 2018 & $32,157.3$ & $19,769.05$ & 29.34 & $23,745.45$ \\
\hline 2019 & $34,354.4$ & $19,987.93$ & 23.01 & $24,363.85$ \\
\hline
\end{tabular}

Source: Central Bank Nigeria Statistical Bulletin, 2019. 